\title{
Childhood lead exposure in France: benefit estimation and partial cost-benefit analysis of lead hazard control
}

\author{
Céline Pichery $^{1 *}$, Martine Bellanger ${ }^{1}$, Denis Zmirou-Navier ${ }^{1,2,3}$, Philippe Glorennec ${ }^{1,6}$, Philippe Hartemann ${ }^{2,3}$ \\ and Philippe Grandjean ${ }^{4,5}$
}

\begin{abstract}
Background: Lead exposure remains a public health concern due to its serious adverse effects, such as cognitive and behavioral impairment: children younger than six years of age being the most vulnerable population. In Europe, the lead-related economic impacts have not been examined in detail. We estimate the annual costs in France due to childhood exposure and, through a cost benefit analysis (CBA), aim to assess the expected social and economic benefits of exposure abatement.
\end{abstract}

Methods: Monetary benefits were assessed in terms of avoided national costs. We used results from a 2008 survey on blood-lead (B-Pb) concentrations in French children aged one to six years old. Given the absence of a threshold concentration being established, we performed a sensitivity analysis assuming different hypothetical threshold values for toxicity above $15 \mu \mathrm{g} / \mathrm{L}, 24 \mu \mathrm{g} / \mathrm{L}$ and $100 \mu \mathrm{g} / \mathrm{L}$. Adverse health outcomes of lead exposure were translated into social burden and economic costs based on literature data from literature. Direct health benefits, social benefits and intangible avoided costs were included. Costs of pollutant exposure control were partially estimated in regard to homes lead-based paint decontamination, investments aiming at reducing industrial lead emissions and removal of all lead drinking water pipes.

Results: The following overall annual benefits for the three hypothetical thresholds values in 2008 are: $€ 22.72$ billion, €10.72 billion and $€ 0.44$ billion, respectively. Costs from abatement ranged from €0.9 billion to 2.95 billion/year. Finally, from a partial CBA of lead control in soils and dust the estimates of total net benefits were $€ 3.78$ billion, $€ 1.88$ billion and $€ 0.25$ billion respectively for the three hypothesized $\mathrm{B}-\mathrm{Pb}$ effect values.

Conclusions: Prevention of childhood lead exposure has a high social benefit, due to reduction of $\mathrm{B}-\mathrm{Pb}$ concentrations to levels below $15 \mu \mathrm{g} / \mathrm{L}$ or $24 \mu \mathrm{g} / \mathrm{L}$, respectively. Reducing only exposures above $100 \mu \mathrm{g} / \mathrm{L}$ B-Pb has little economic impact due to the small number of children who now exhibit such high exposure levels. Prudent public policies would help avoiding future medical interventions, limit the need for special education and increase future productivity, and hence lifetime income for children exposed to lead.

\section{Background}

Lead is a well known toxic metal, and current exposures in children constitute a reason for concern [1]. In France, lead has multiple anthropogenic sources and is now mainly present in its inorganic form in the environment $[2,3]$. The relative importance of different sources depends on the blood lead range. For the general

\footnotetext{
* Correspondence: celine.pichery@ehesp.fr

${ }^{1}$ EHESP School of Public Health, CS 74312 - 35043 Rennes Cedex, France Full list of author information is available at the end of the article
}

European population [1] and for children [4], food is usually the major source of exposure, with cereals and vegetables products contributing mostly to dietary lead exposure. Tap water can also, in some cases, be an important contributor because of the presence of lead pipes in old homes and public plumbing systems. Degradation of old lead-based paint results in the contamination of indoor dust that can be inhaled or ingested, thus adding to the sources already mentioned. Other incidental sources of lead exposure include consumer products,

\section{Biomed Central}


notably toys, and hobbies or occupations involving lead [3]. After the ban of leaded petrol, air concentrations have decreased substantially and are now due almost entirely to industrial emissions [5,6]. In France, the targeted regulations to decrease elevated $\mathrm{B}-\mathrm{Pb}$ concentrations, control measures and screening strategies have progressively reduced risks from lead pipes, lead-based paint in houses built before 1949 and contamination at specific industrial sites [3]. Children under six years of age have the highest exposure to lead because of several factors such as greater hand dust contamination, frequent hand-to-mouth transfer and higher absorption rates than adults. Also, lead can pass through the placenta so that the child is born with lead from the mother's cumulated body burden [7]. Overall, lead poisoning is still a serious hazard for children and causes significant neurologic damage linked to cognitive and behavioral impairment $[1,8]$. Although frequently overlooked, the timing of the dose in regard to windows of highest vulnerability in children is also important $[9,10]$.

The first national study carried out in France in 1999 by the National Institute of Health and Medical Research (INSERM) showed that 2\% of French children aged one to six years of age had $\mathrm{B}-\mathrm{Pb}$ concentrations $>100 \mu \mathrm{g} / \mathrm{L}$ (i.e. approximately 85,000 children); the geometric mean blood-lead concentration was $37 \mu \mathrm{g} / \mathrm{L}$ [2]. This exposure level was similar to other Western European countries [11]. In a new survey, 2008-2009, the National Institute for Health Surveillance (InVS) [12] found that the geometric mean $\mathrm{B}-\mathrm{Pb}$ had decreased to $15 \mu \mathrm{g} / \mathrm{L}$ (standard deviation [SD], 1.6) among children aged 1-6 years, and the prevalence of $\mathrm{B}-\mathrm{Pb}$ concentrations $>100 \mu \mathrm{g} / \mathrm{L}$ had dwindled to $0.11 \%$ (i.e. 5,333 children) [12]. Nonetheless, many children are still at risk because there is no evidence for a lead toxicity threshold. The $\mathrm{B}-\mathrm{Pb}$ concentration intervention value in the US and France is $100 \mu \mathrm{g} / \mathrm{L}$; above this limit the subject is considered as lead poisoning by public health authorities and is supposed to be reported in the French National system of surveillance of children's B-Pb concentrations. At lower values lead toxicity may still cause damage to nervous system functions, including decreased nerve conduction velocity and cognitive deficits [1], and significant neurologic damage may occur as a result of both intrauterine and postnatal exposures $[13,14]$. The intellectual decrement may be expressed in terms of a loss of IQ points for every $\mu \mathrm{g} / \mathrm{L}$ unit increase of the $\mathrm{B}-\mathrm{Pb}$, but this loss slope is steeper at $\mathrm{B}-\mathrm{Pb}$ concentrations lower than $100 \mu \mathrm{g} / \mathrm{L}$ than at higher levels [14]. At the individual level, this drop may seem small and inconsequential, but at the population level, small effects in many individuals are likely to have an impact on the overall societal benefits [11]. The effects include lower school performance and educational attainment, which may influence societal adaptation and economic success, with some affected children showing juvenile delinquency $[11,15]$. Therefore, improvements in cognitive ability will benefit society by raising both economic wealth and overall wellbeing. Several economic studies, mainly in the US, have estimated the costs and risks associated with infantile lead poisoning and lead toxicity, in some cases weighing them against the costs associated with lead-based paint control and other efforts. These studies have also calculated the potential increased financial earnings that would result if the level of lead in children's blood were to be reduced $[[8,16]$, and [17]]. In France, studies are mostly epidemiological, focusing on targeted screening and lead exposure. There have been few economic assessments of lead's impact on the children's health, with the exception of the studies by Chanel [18-20], while Fassin and colleagues highlighted the social aspects of lead exposure [21]. The present paper aims to fill the gap and contribute at least in part to a cost benefit analysis (CBA), while taking into account that there is "no single estimate that accurately reflects the costs and the benefits of lead hazard control" [8]. We first summarize the childhood lead exposure situation in France and related information on the main exposure media and risk factors. We then estimate the monetary benefits that can be expected from pollutant abatement, with estimates of investment costs to achieve this reduction, as based on available information. Lastly, we compare the main findings of this study and discuss the role of CBA in a societal perspective of public policy development.

\section{Methods}

\section{Population studied and sources of lead exposure}

We based our estimations on the InVS study [12]. The geometric mean of children's $\mathrm{B}-\mathrm{Pb}$ concentrations in France was found to be $15.1 \mu \mathrm{g} / \mathrm{L}$, with a SD of $1.6(\log$ normal distribution). We used the same target population consisting of 4.7 million children from one to six years of age according to the National Institute for Statistics and Studies [12]. Table 1 shows the distribution and the number of children exceeding the hypothetical threshold values for this cohort. Estimates were made based on the entire cohort in order to highlight the global economic impact on the most sensitive segment of the population to lead exposure. Derived from this estimate, the size of the population experiencing lead poisoning (at $\mathrm{B}-\mathrm{Pb} \geq 100 \mu \mathrm{g} / \mathrm{L}$ ) was 5,333 [12]. We used data from the French National system of surveillance of children's B-Pb concentrations (SNSPE, 2005-2007) [22] to assess the distribution of risk factors among children with $\mathrm{B}-\mathrm{Pb}$ concentrations $\geq 100 \mu \mathrm{g} / \mathrm{L}$. Based on the SNSPE data, $74 \%$ of the cases were associated with poor housing: old buildings (i.e. those built before 1949), degraded, with 
Table 1 Estimates of total direct health costs within B-Pb concentration ranges for the French child population $\left(\epsilon_{2008}\right)$

\begin{tabular}{|c|c|c|c|c|}
\hline Blood-lead concentrations range $(\mu \mathrm{g} / \mathrm{L})$ & $\%$ of children aged 1 to 6 years $^{\mathrm{a}}$ & Number of children ${ }^{a}$ & Unit cost $(€)$ & Total costs (€ million) \\
\hline $\mathrm{B}-\mathrm{Pb}<15$ & 50.00 & $2,348,091$ & 0 & 0 \\
\hline $15 \leq \mathrm{B}-\mathrm{Pb}<24$ & 35.1 & $1,648,975$ & 120 & 198 \\
\hline $24 \leq \mathrm{B}-\mathrm{Pb}<100$ & 14.8 & 693,783 & 120 & 83 \\
\hline $\mathrm{B}-\mathrm{Pb} \geq 100$ & 0.1 & 5,333 & 2,932 & 16 \\
\hline
\end{tabular}

${ }^{a}$ On the basis of INSEE data and INVS results, 2010.

Table 1 shows the direct health cost $\mathrm{B}_{\text {med }}$ within $\mathrm{B}-\mathrm{Pb}$ concentration ranges for the French child population. $\mathrm{B}_{\text {screening }} 15-24$ and $\mathrm{B}_{\text {screening24-100 }}$ amount to $120 €$ per child and $B_{\text {treatment } \geq 100}$ is estimated to $€ 2,932$ which equals to $\left(\left(1,819^{*} 0.73+4,851 * 0.27\right)+294\right)$ per child.

humidity and lead-based paint still present on walls or windows and door frames. Another $4 \%$ were estimated to be linked to industrial emissions and only $1 \%$ to contaminated water. However, it is worth noting that these data rely upon screening programmes whose results may vary according to the main sources of exposure in different regions, and also according to the screening strategy. For example, in the Paris region, the main exposure media for high $(\geq 100 \mu \mathrm{g} / \mathrm{L}) \mathrm{B}-\mathrm{Pb}$ concentrations were contaminated dust and soils. In comparison, exposure of the screened children in the North of France region was mainly linked to the old Metaleurop smelter which represented $42 \%$ of all screened cases. Based on these same data, all regions included, we thus considered that contaminated soils and dust or ingested flakes from degraded paint in old homes $<1949$ were the main risk factor in three out of four cases for $\mathrm{B}-\mathrm{Pb}$ concentrations $\geq 100 \mu \mathrm{g} / \mathrm{L}$. These results are in line with US data where $70 \%$ of cases with high $\mathrm{B}-\mathrm{Pb}$ concentrations were due to lead-based paint [23].

Now, $99 \%$ of children from one to six years old have B-Pb concentrations $<100 \mu \mathrm{g} / \mathrm{L}$ (Table 1). Glorennec and colleagues [4] estimated the fractions of exposure due to different sources for this population under ordinary exposure conditions. We selected these data to assess the contribution of the most prominent risk factors at the $75^{\text {th }}$ percentile of the distribution (P75). Food was found to constitute the main exposure medium (83\%), followed by dust and soil (16\%) and water (1\%).

\section{Assessment of IQ decrements}

Environmental lead exposure in children may cause cognitive impairment among children $\leq 6$ years, as assessed by measurement of IQ. The international pooled analysis by Lanphear and colleagues [14] established a nonlinear, negative relationship between IQ and $\mathrm{B}-\mathrm{Pb}$ concentrations. Between 24 and $100 \mu \mathrm{g} / \mathrm{L}$, the decrement per unit of $\mu \mathrm{g} / \mathrm{L}$ increase in $\mathrm{B}-\mathrm{Pb}$ amounted to 3.9 IQ points (95\% CI, 2.4-5.3). At higher exposures, i.e. from to 100 to $200 \mu \mathrm{g} / \mathrm{L}$, and from 200 to $300 \mu \mathrm{g} / \mathrm{L}$, the drop in IQ points was 1.9 (95\% CI, 1.2-2.6), and 1.1 (95\% CI, 0.7-1.5), respectively. Thus far, there are few studies so far examining exposures below $24 \mu \mathrm{g} / \mathrm{L}$. However, as concluded by the European Food Authority Safety
(EFSA): "no threshold for these effects has been identified, and the evidence suggests that the response at $\mathrm{B}-\mathrm{Pb}$ concentrations below $100 \mu \mathrm{g} / \mathrm{L}$ is steeper than at higher exposure levels" [1]. In addition, a recent risk assessment study by the California Environmental Protection Agency (CEPA) calculated that a $10-\mu \mathrm{g} / \mathrm{L}$ increase in $\mathrm{B}-\mathrm{Pb}$ in the range of $10-100 \mu \mathrm{g} / \mathrm{L}$ resulted in a population-level decrement of one IQ point $[24,25]$.

Given that no threshold for lead toxicity has been established, we conducted a sensitivity analysis assuming that loss of IQ in the study population starts at values exceeding $15 \mu \mathrm{g} / \mathrm{L}$, respectively 24 and 100 , following a "what if ?" approach; the first value is close to the geometric mean of B-Pb among French children $(15.1 \mu \mathrm{g} / \mathrm{L})$ [12]. We assumed a loss of one IQ point from 15 to $24 \mu \mathrm{g} / \mathrm{L}$. And further used the dose-effect decrements calculated by Lanphear and colleagues for values from 24 to $100 \mu \mathrm{g} / \mathrm{L}$, and a loss of 1.9 IQ points from $100 \mu \mathrm{g} / \mathrm{L}$ to $200 \mathrm{ug} / \mathrm{L}$.

\section{Cost Benefit Analysis}

Cost benefit analysis (CBA) is often used in health care assessment, as it links the costs of a strategy to its results or benefits expressed in monetary units. The rationale of CBA implies that an intervention should be undertaken if the sum of its benefits (B) is greater than the sum of its costs $(C)$. An alternative way of expressing this is to say that its net benefit $(B-C)$ is positive or that its $B / C$ ratio is greater than 1 . The preferred option will be the one which maximizes this net benefit, and consequently the new CBA-based health strategy will provide a net benefit to society [26-28].

For this study, we based our estimation on the yearly economic impact of reduction of lead exposure for each birth cohort (children born within one calendar year) and compared these social benefits to investments needed to reduce exposure and control risk factors. Because little information is available on the investments required in France to abate lead exposure, we focused our evaluation on the benefit side, and provided preliminary estimates of costs of exposure abatement. We assessed the benefits in terms of avoided costs (see Figure 1).

The calculation of benefits took into account the range of $\mathrm{B}-\mathrm{Pb}$ concentrations above the thresholds 


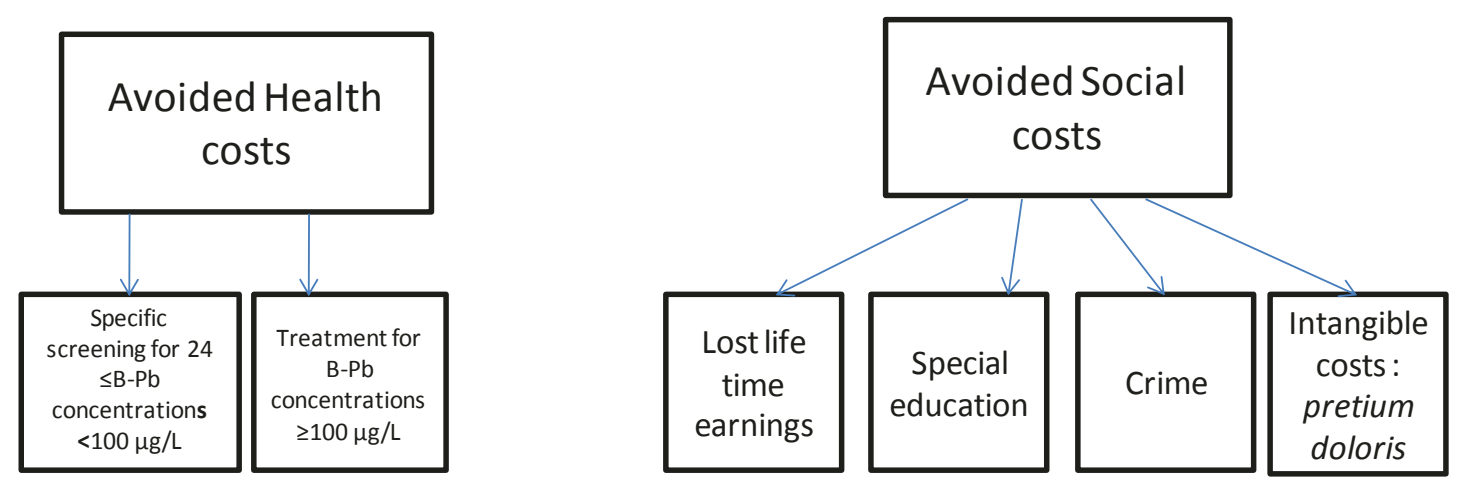

Figure 1 Monetary benefits assessed in terms of avoided costs.

already defined. These estimates of benefits B are defined as follows:

$$
\mathrm{B}=\mathrm{B}_{\text {med }}+\left[\mathrm{B}_{\text {earn }} / \mathrm{w}\right]+\mathrm{B}_{\text {spec.ed }}+\mathrm{B}_{\text {crime }}+\mathrm{B}_{\text {other }}
$$

where $B_{\text {med }}$ are the direct avoided costs; $B_{\text {earn }} / w$ are the lost lifetime earnings, applying a discount factor $\mathrm{w}$ equal to $(1+\mathrm{s})^{\mathrm{t}}$, with a $3 \%$ discount rate (s) to a time horizon $t$ about 30 years; $B_{\text {spec.ed }}$ are the costs for special education; $B_{\text {crime }}$ are the costs due to juvenile delinquency - the latter three being social benefits; and $B_{\text {other }}$ are the intangible costs. For our estimations, we used the purchasing parity power (GDPppp\$- $€$ ) when applying American cost data in the French setting. The estimates are inflation adjusted $[26,29,30]$ and performed for one year (2008).

\section{Annual benefit estimation Health benefits: costs of avoiding lead poisoning

$$
\mathrm{B}_{\text {med }}=\mathrm{B}_{\text {screening15-24 }}+\mathrm{B}_{\text {screening24-100 }}+\mathrm{B}_{\text {treatment }} \geqslant 100
$$

Based on the InVS data B-Pb distribution (Table 1), we estimated direct costs $B_{\text {med }}$ from the component costs $B_{\text {screening15-24, }}, B_{\text {screening24-100 }}$ and $B_{\text {treatment }} \geq 100$ for screening and treatment within the observed $\mathrm{B}-\mathrm{Pb}$ range (15-24 $\mu \mathrm{g} / \mathrm{L}$ as "15-24", 24-100 $\mu \mathrm{g} / \mathrm{L}$ as "24-100" and $\geq 100 \mu \mathrm{g} / \mathrm{L}$ as " $\geq 100$ ", respectively). We calculated $\mathrm{B}_{\text {screening15-24, }}, \mathrm{B}_{\text {screening24-100 }}$ and $\mathrm{B}_{\text {treatment }} \geq 100$ as costs of screening, hospitalization, and medical consultations within the observed $\mathrm{B}-\mathrm{Pb}$ range and in agreement with the French recommendations [31] for children aged six months to six years. Part of these costs were based on a pilot study undertaken by the Aubervilliers local authority, which provided reference costs for 2006, that were inflation-adjusted for 2008 [3]. B- $\mathrm{Pb}<15 \mu \mathrm{g} / \mathrm{L}$ was considered as not requiring medical attention. Since treatment is used only for children above $100 \mu \mathrm{g} / \mathrm{L}$, subjects with lower values incur only screening costs which amount to $120 €$ per child in 2008, labeled as $B_{\text {screening } 15-24}$ and $B_{\text {screening24-100, }}$ respectively. The direct health cost estimates for $\mathrm{B}-\mathrm{Pb} \geq$ $100 \mu \mathrm{g} / \mathrm{L}$ up to $300 \mu \mathrm{g} / \mathrm{L}$ is given by $B_{\text {treatment }} \geq 100$. In this case, the screening cost per child was estimated from $€ 1,819$ for screened children ( $73 \%$ of all cases) to $€ 4,851$ for new cases of lead toxicity (27\% of all cases [3]). We also added unit costs for medical follow-up: $€ 294$, medication included, according to Brown [32].

Unit cost estimate of outpatient chelation treatment, without medication, was $€ 3,491$ of which $€ 2,365$ and $€ 1,126$ for nursing follow-up and in-home hospitalization, respectively. This cost should be added to screening costs for children with $\mathrm{B}-\mathrm{Pb}$ concentrations $\geq 300 \mu \mathrm{g} / \mathrm{L}$ [33]. Hence, $B_{\text {treatment }} \geq 100$, equal to $€ 2,932$ $[(1,819 * 0.73+4,851 * 0.27)+294]$ for lead toxicity at B-Pb $\geq 100 \mu \mathrm{g} / \mathrm{L}$, should be $€ 6,423(2,932+3,491)$ for $\mathrm{B}-\mathrm{Pb} \geq$ $300 \mu \mathrm{g} / \mathrm{L}$. However, due to the lack of information on the number of children with $\mathrm{B}-\mathrm{Pb}$ concentrations $\geq 300$ $\mu \mathrm{g} / \mathrm{L}$ in the InVS study, we assumed that all screening costs were $€ 2,932$ for $\mathrm{B}-\mathrm{Pb} \geq 100 \mu \mathrm{g} / \mathrm{L}$.

Indirect economic benefits related to health improvement In our case, part of the indirect costs represents the productivity losses to society due to lead toxicity. For the purpose of this study, the indirect costs include the loss of lifetime earnings, the costs of special education, and the costs of juvenile delinquency.

\section{IQ and lost lifetime earnings due to lead poisoning}

The lifetime costs associated with lower earning potential caused by lead toxicity is based on a linear relationship between the loss of IQ due to lead and expected lifetime earnings. From the studies by Lanphear and colleagues [14], and the CEPA study [24], we assumed 1 IQ point loss from 15 to $24 \mu \mathrm{g} / \mathrm{L}$. According to Lanphear's IQ decrements, we used 3.9 IQ points from 24 to $100 \mu \mathrm{g} / \mathrm{L}$, to which, we added the first IQ point loss, $(1+3.9=4.9)$. We applied an average IQ point loss of 3.9/7.6 $=0.51$ point per $10 \mu \mathrm{g} / \mathrm{L}$ within this range. According to the available data in [12], we used percentile values for the 
intermediate calculations between 24 and $100 \mu \mathrm{g} / \mathrm{L}$. Above $100 \mu \mathrm{g} / \mathrm{L}$, the IQ point loss was 6.8 (= $1+3.9$ +1.9) per $100 \mu \mathrm{g} / \mathrm{L}$ (Table 2). Although the IQ and the $\mathrm{B}-\mathrm{Pb}$ assessments were usually made at 7 years, similar associations were found for lead concentrations at younger ages, but they are considered less stable $[14,34]$. We therefore applied these IQ losses to the selected 1-6 years children. We followed Gould's method where estimates of IQ decrement were based on the data from the main published studies $[16,17,35]$, and we drew from her 2006 estimate of $\$_{2006} 17,815$ for the present value of incremental lifetime earnings. We adjusted it for inflation to $€_{2008}$ and the loss was thus estimated to be $€ 17,363$ per IQ point in 2008. Again,

$$
\mathrm{B}_{\text {earn }}=\mathrm{B}_{\text {earn } 15-24}+\mathrm{B}_{\text {earn } 24-100}+\mathrm{B}_{\text {earn }} \geqslant 100
$$

where $B_{\text {earn }}$ are the total lost lifetime earnings due to lead toxicity, with $\mathrm{B}_{\text {earn } 15-24}$ for increased $\mathrm{B}-\mathrm{Pb}<24 \mu \mathrm{g} / \mathrm{L}$, $\mathrm{B}_{\text {earn24-100 }}$ for $\mathrm{B}-\mathrm{Pb}$ from $24 \mu \mathrm{g} / \mathrm{L}$ to $100 \mu \mathrm{g} / \mathrm{L}$, and $\mathrm{B} \mathrm{B}_{\text {earn }} \geq 100$ for $\mathrm{B}-\mathrm{Pb} \geq 100 \mu \mathrm{g} / \mathrm{L}$.

\section{Special education}

Children with elevated $\mathrm{B}-\mathrm{Pb}$ concentrations have an increased risk of enrollment in special education. Two categories of French institutions take care of children and young adults between three and 20 years old with cognitive and behavioral impairment. The Medical Educational Institutes (IME) educates children with intellectual deficiency symptoms while the Educational and Therapeutic Institutes (ITEP) do so for behavioral problems. According to Schwartz [16], 20\% of children with $\mathrm{B}-\mathrm{Pb}>250 \mu \mathrm{g} / \mathrm{L}$ need special education. A more recent study suggested that the need for such service could start below this concentration [36], i.e. when B-Pb exceeds $100 \mu \mathrm{g} / \mathrm{L}$. Lyngbye and al. showed that, even at low levels of lead exposure, the need for special education increases with the exposure level [37]. Another reference also showed for children with $\mathrm{B}-\mathrm{Pb} \geq 100 \mu \mathrm{g} / \mathrm{L}$ lower intelligence and behavior changes [38]. From their findings, we estimated the need for special education to be $10 \%$ for children with $\mathrm{B}-\mathrm{Pb} \geq 100 \mu \mathrm{g} / \mathrm{L}$, the cost denoted $B_{\text {spec.ed } \geq 100 \text {. }}$.

The French national data show that $79.8 \%$ and $20.1 \%$ children with cognitive and behavioral deficiencies are in IME and ITEP, respectively [39]. The estimated average annual cost per child was $€ 38,958$ in IME and $€ 48,255$ in ITEP in 2008 [40].

\section{Violent behavior leading to juvenile delinquency}

The Nevin's study [36] recent evidence of a link between prenatal and early-childhood lead exposure and increased risk of criminal behavior later in life illustrated that showed a strong association between preschool $\mathrm{B}-\mathrm{Pb}$ and subsequent crime rate trends over several decades in various countries, including France. The relationship was characterized by best-fit lags consistent with neurobehavioral damage in the first year of life and the know peak age of offending for index crime, burglary, and violent crime $[36,41]$. Several other studies support the link between preschool lead exposure and aggressive or delinquent adolescent behavior and subsequent criminal violence $[42,43]$. We therefore estimated the costs linked to lead-associated crime on the basis of Gould's approach [8]. We first obtained the total number of violent/aggressive specific crimes committed in 2008 from the French national observatory of Delinquency [44]. We then used data from Nevin [36] to estimate the share of each of the crimes that might be associated with lead toxicity. These include burglaries $(2.4 \%)$, robberies $(0.7 \%)$, aggravated assaults $(3.1 \%)$, rape $(2.7 \%)$, and murder $(5.4 \%)$. The total lead-linked crimes were computed on the basis of the French population aged 13-60 years liable to commit a violent act $[45]$. We next calculated $\left(B_{\text {crime }}\right)$ the costs directly associated with each sort of crime and the total cost of lead-linked crimes.

Table 2 Lifetime earning losses per year of the selected cohort according to IQ point losses within B-Pb concentration ranges $\left(\epsilon_{2008}\right)$

\begin{tabular}{|c|c|c|c|c|c|}
\hline $\begin{array}{l}\text { Blood-lead } \\
\text { concentrations range } \\
(\mu \mathrm{g} / \mathrm{L})\end{array}$ & $\begin{array}{c}\text { IQ point loss } \\
\text { assumptions }{ }^{a, b}, c\end{array}$ & $\begin{array}{l}\text { Number of } \\
\text { children } d\end{array}$ & $\begin{array}{c}\text { Number of IQ } \\
\text { point losses }\end{array}$ & $\begin{array}{c}\text { Total Costs } \\
{\text { (€billion })^{\mathrm{e}}}^{\text {To }}\end{array}$ & $\begin{array}{l}\text { Lost life time earnings with a } \\
\text { discount factor } w_{30} \text { (€billion) }\end{array}$ \\
\hline $\mathrm{B}-\mathrm{Pb}<15$ & 0 & $2,348,091$ & 0 & 0 & 0 \\
\hline $15 \leq \mathrm{B}-\mathrm{Pb}<24$ & 1 & $1,648,975$ & $1,648,975$ & 28.6 & 11.8 \\
\hline $24 \leq \mathrm{B}-\mathrm{Pb}<100$ & $4.9(1+3.9)$ & 693,783 & $1,421,769$ & 24.7 & 10.2 \\
\hline $\mathrm{B}-\mathrm{Pb} \geq 100$ & $6.8(1+3.9+1.9)$ & 5,333 & 36,265 & 0.6 & 0.3 \\
\hline TOTAL & & $4,696,182$ & $3,107,009$ & 53.9 & 22.3 \\
\hline
\end{tabular}

Based on ${ }^{a}$ EFSA conclusions [1], ${ }^{b}$ CEPA [24], ${ }^{c}$ Lanphear and colleagues. [14], ${ }^{d}$ InVS data [11] and ${ }^{\text {e }}$ Gould [8]

Table 2 presents lifetime earning losses per year of the selected cohort according to IQ point losses within B-Pb concentration ranges. The IQ point loss assumption were $1,4.9(=1+3.9)$ with 0.51 point per $10 \mu \mathrm{g} / \mathrm{L}$ within this range, and $6.8(=1+3.9+1.9)$ IQ point losses per $100 \mu \mathrm{g} / \mathrm{L}$ within this range, from 15 to $24 \mu \mathrm{g} / \mathrm{L}$, from 24 to $100 \mu \mathrm{g} / \mathrm{L}$, and above $100 \mu \mathrm{g} / \mathrm{L}$ respectively. The loss per IQ point was estimated to be $\epsilon_{2008} 17,363$. Based on the equation 3 ( $\left.B_{\text {earn }}=B_{\text {earn } 15-24}+B_{\text {earn24-100 }}+B_{\text {earn }} \geq 100\right)$, the total lost lifetime earnings due to lead toxicity $B_{\text {earn }}$ were estimated, with $B_{\text {earn } 15-24}$ for increased B-Pb $<24 \mu \mathrm{g} / \mathrm{L}, \mathrm{B}_{\text {earn24-100 }}$ for $\mathrm{B}-\mathrm{Pb}$ between $24 \mu \mathrm{g} / \mathrm{L}$ and $100 \mu \mathrm{g} / \mathrm{L}$, and $B_{\text {earn }} \geq 100$ for $B-P b \geq 100 \mu \mathrm{g} / \mathrm{L}$. We applied a discount factor $W_{30}$ on the total costs and we obtained $€ 22.3$ billion, $€ 10.5$ billion and $€ 0.3$ billion, respectively for the year 2008 . 
We used French data when available, and otherwise US data in the absence of French data for direct costs of victims and overhead costs of justice and incarceration and for lost earnings for both criminals and victims, as well $[46,47]$. All costs were adjusted by the ratio of US and French crime rates (the US rate crime of 5.6 per 100,000 being much greater than the French rate crime, 1.7 per 100,000 , in 2005) $[48,49]$. In this case,

$$
\mathrm{B}_{\text {crime }}=\mathrm{B}_{\text {crime }} \geqslant 100
$$

where $\mathrm{B}_{\text {crime }}$ are the cost estimates for $\mathrm{B}-\mathrm{Pb} \geq 100 \mu \mathrm{g} / \mathrm{L}$ Intangible costs

In addition, suffering and degradation of the quality of life associated with lead poisoning and its side effects had to be taken into account. Intangible costs, mentioned $\mathrm{B}_{\text {other, }}$ while difficult to measure were taken into account using the "pretium doloris" approach. These costs were estimated for children with $\mathrm{B}-\mathrm{Pb}$ concentrations $\geq 100 \mu \mathrm{g} / \mathrm{L}$. The Metal Blanc factory of BourgFidèle (Ardennes administrative subdivision, North East France), specializing in the recovery of lead from used batteries (drum kits), was condemned for putting lives at risk in September 2009. The judge called for $€ 120,000$ of 'damages and interests' to the victims, the cases of six families having been declared valid. The judgment called for $€ 8,000$ for each child with $\mathrm{B}-\mathrm{Pb}$ concentrations $\geq 100 \mu \mathrm{g} / \mathrm{L}$ [50]. We note:

$$
\mathrm{B}_{\text {other }}=\mathrm{B}_{\text {other }} \geqslant 100
$$

\section{Annual total benefits}

In summary, the total benefits (avoided costs) are therefore given by

$$
\begin{aligned}
& \mathrm{B}=\mathrm{B}_{\text {screening } 15-24}+\mathrm{B}_{\text {screening } 24-100}+\mathrm{B}_{\text {treatment }} \geqslant 100 \\
& +\left(\mathrm{B}_{\text {earn } 15-24}+\mathrm{B}_{\text {earn } 24-100}+\mathrm{B}_{\text {earn }} \geqslant 100\right) /(1+\mathrm{s})^{\mathrm{t}} \\
& +\mathrm{B}_{\text {spec.ed }} \geqslant 100+\mathrm{B}_{\text {crime }} \geqslant 100+\mathrm{B}_{\text {other }} \geqslant 100
\end{aligned}
$$

Final estimation included confidence intervals and a sensitivity analysis using different key assumptions from the American and European data, on which the calculations were based. Benefits were estimated according to different $\mathrm{B}-\mathrm{Pb}$ hypothetical threshold values, i.e. $15 \mu \mathrm{g} /$ $\mathrm{L}, 24 \mu \mathrm{g} / \mathrm{L}$ and $100 \mu \mathrm{g} / \mathrm{L}$, respectively.

\section{Abatement cost estimation Estimates of costs associated with reduction of $\mathrm{B}-\mathrm{Pb}$ concentrations}

Due to insufficient cost data related to control of lead hazards, only preliminary estimates of cost incurred by pollution control were performed, as indicated below. We estimated total lead-based paint decontamination costs, partial costs of industrial emission abatement and lead pipe removal costs.

\section{Total lead-based paint decontamination costs to remediate} French houses

These costs, denoted $\mathrm{C}_{\text {paint }}$, were calculated on the basis of InVS [3] and INSEE data [2] on 37,382 lead-paint based homes and using an average estimated removal cost per home. According to the SNSPE data [22] and to Glorennec and colleagues, [4] lead in soils and dust from the leadbased paint in homes built before 1949 represent $74 \%$ and $16 \%$ of cases of childhood lead intoxication for blood lead levels greater and lower than $100 \mu \mathrm{g} / \mathrm{L}$, respectively. We estimated the costs of decontaminating French houses with lead-based paint following the data from the national Agency of the housing environment (ANAH) scenarios regarding elimination of lead presence. Only 37,382 homes had to be decontaminated among about 28 million French homes: therefore we considered that these operations could be performed once and for-all in one year's time.

\section{Industrial investments costs to reduce lead exposure}

The costs of investments (denoted $C_{\text {ind }}$ ) to control industrial lead pollution and reduce lead emissions both in air and water were also estimated. They include technologies to recycle and reduce presence of lead in batteries and in glass, abatement of diffuse emissions through increase in the efficiency of recycling, capture and treatment of the contaminated discharges. Investment costs were weighted per factory volumes based on data from a National Institute for Industrial Environment and Risks - (INERIS) [51]. These were annual costs.

\section{Costs to eliminate water lead pipes}

These costs, denoted $\mathrm{C}_{\mathrm{water}}$, were estimated following the High Council of Hygiene (CSHPF) and the French Food Safety Agency (AFSSA) recommendations for removing all lead pipes used in public water supply and in household plumbing, in order to reach a lead concentration of $\leq 10 \mu \mathrm{g} / \mathrm{L}$ before the end of year 2013. $C_{\text {water }}$ based on the estimations of the European Institute Reasoned Management for the Environment (IEGRE) [52], $\mathrm{C}_{\text {water }}$ was found to be $€ 10$ billion for household pipes, and $€ 4$ billion for public pipes. We calculated an investment plan over five years to reach the above mentioned objective, (denoted $\mathrm{C}_{\text {pwater }}$ ). Although a longer investment plan could have been chosen, we calculated the annual costs for an investment plan over 5 years to cover the expenses. We used ANAH estimates and French or US data, according to which were available [3,53-55].

\section{Results}

\section{Annual Benefits}

Direct health care costs were estimated in accordance with equation (2) and were found to be $€ 0.297$ billion/ year as shown in table 1 . Direct health costs represented $0.14 \%$ of the total French health expenditure in 2008. 
Table 1 reports the direct health cost estimates $B_{\text {screen- }}$ ing15-24, $\mathrm{B}_{\text {screening24-100 }}$ and $\mathrm{B}_{\text {treatment }} \geq 100$ per $\mathrm{B}-\mathrm{Pb}$ concentrations range.

Lost lifetime earnings ranged from $€ 0.6$ billion ( $B_{\text {earn } \geq}$ $100)$ to $€ 53.3$ billion ( $B_{\text {earn15-24 }}+B_{\text {earn24-100 }}$ ) according to $\mathrm{B}-\mathrm{Pb}$ concentrations $\geq$ and $<100 \mu \mathrm{g} / \mathrm{L}$, respectively, as presented in Table 2 . Thus, $\mathrm{B}_{2}$ estimates were $€ 53.9$ billion per year for the full $\mathrm{B}-\mathrm{Pb}$ range. We note that the loss of IQ associated with $\mathrm{B}-\mathrm{Pb}$ concentrations between $15 \mu \mathrm{g} / \mathrm{L}$ and $100 \mu \mathrm{g} / \mathrm{L}$ amounted to more than $99 \%$ of the total estimated costs. Thus, the loss of IQ would be marginally influenced by the number underestimating of children having a high $\mathrm{B}-\mathrm{Pb} \geq 100 \mu \mathrm{g} / \mathrm{L}$. Applying the discount factor $\mathrm{w}\left(\mathrm{w}_{30}=\left(1 /(1.03)^{30}\right)\right)$ on lost life-time earnings, we obtained the estimate: $€ 22.3$ billion above $15 \mu \mathrm{g} / \mathrm{L}, € 10.5$ billion above $24 \mu \mathrm{g} / \mathrm{L}$ and $€ 0.3$ billion above $100 \mu \mathrm{g} / \mathrm{L}$.

For special education, the annual national cost estimate $B_{\text {spec.ed } \geq 100}$ was $€ 14.53$ million for $10 \%$ of children with $\mathrm{B}-\mathrm{Pb}$ concentrations $\geq 100 \mu \mathrm{g} / \mathrm{L}$ in need of special education.

For deviant behavior and crime, a reduction of $10 \mu \mathrm{g} / \mathrm{L}$ in preschool $\mathrm{B}-\mathrm{Pb} \geq 100 \mu \mathrm{g} / \mathrm{L}$ would result in 4,770 fewer burglaries, 102 fewer robberies, and 2,206 for aggravated assaults, 171 for rapes, and 29 for murders. In France, the total estimated cost of lead-linked crimes $\left(B_{\text {crime }} \geq 100\right)$ was approximately $€ 61.8$ million per year, as shown in Table 3 , this accounted for $0.3 \%$ of the total cost of crime in 2008 [46].

Intangible costs for the population with $\mathrm{B}-\mathrm{Pb} \geq 100 \mu \mathrm{g} / \mathrm{L}$ were calculated as compensations, resulting in a total cost of $€ 42.7$ million ( $B_{\text {other } \geq 100}$ ).

Based on these estimates, we calculated the total benefit of prevented lead toxicity as the sum of avoided costs. They included specific screening and treatment costs of lead poisoned children ( $€ 0.3$ billion), lost lifetime earnings ( $€ 53.9$ billion), special education costs
(€0.145 billion), intangible costs ( $€ 0.0427$ billion), and the direct costs related to crime (€0.0618 billion). We obtained the following total benefits for the three sensitivity analyses hypothetical threshold values of 15, 24 and $100 \mu \mathrm{g} / \mathrm{L}: € 22.72$ billion, $€ 10.72$ billion and $€ 0.44$ billion, respectively, in 2008 (Table 4). The social benefits represented $98.7 \%, 99 \%$ and $96.5 \%$, respectively of the total benefits. A unit benefit was estimated per child and per different $\mathrm{B}-\mathrm{Pb}$ concentration values, as follows $€ 9,676$, $€ 15,334$ and $€ 82,505$, respectively, for the three threshold assumptions.

\section{Abatement Costs}

Table 5 shows that lead-based paint decontamination costs per home ranged from $€ 3,562$ to $€ 9,162$, with $€ 6,562$ as the central estimates, giving total cost estimates $C_{\text {paint }}$ from $€ 245.3$ [€133.1; $\left.€ 342.5\right]$ million in 2008. The annual industrial costs estimated $C_{\text {ind }}$ would have been $€ 28.9$ million in 2008. For water lead pipes, the total estimated costs $C_{\text {water }}$ between $€ 4$ billion and $€ 14$ billion. We applied a $3 \%$ discounting rate for $C^{*}$ paint $+C^{*}$ ind and an investment plan $P$ on five years for $C_{\text {water }}$. Hence, on the basis on available data, annual estimates of total costs of lead hazard control $\mathrm{C}^{*}$ paint $+\mathrm{C}^{*}$ ind $+\mathrm{C}_{\mathrm{P}}$ water ranged from $€ 0.9$ billion to $2.95 €$ billion. Reported per child within the cohort a unit cost was estimated to range from $€ 185$ to $€ 629$.

\section{Net benefits of the removal of lead-based paint in the French houses in 2008}

We first estimated total net benefit induced by the risk factors soils and dust which contributed relatively more to low $\mathrm{B}-\mathrm{Pb}$ values than to high $\mathrm{B}-\mathrm{Pb}$ levels. This net benefit would stem from the reduction of lead hazard exposure and of childhood lead poisoning cases induced by this factor in respect of the costs $C^{*}$ paint associated with the control of lead environmental pollution.

Table 3 The effect of developmental lead exposure on crime in France and the associated annual costs $\left(\epsilon_{2008}\right)$

\begin{tabular}{|c|c|c|c|c|c|}
\hline Crime & $\begin{array}{c}\text { Number of crimes per } 100,000 \\
\text { French residents }(\mathrm{N})^{a}\end{array}$ & $\begin{array}{l}\text { Lead linked crimes per } 100,000 \\
\text { French residents (N) b }\end{array}$ & $\begin{array}{l}\text { Total lead linked } \\
\text { crimes }(\mathrm{N})\end{array}$ & $\begin{array}{l}\text { Costs per } \\
\text { crime }(e)^{c, d}\end{array}$ & $\begin{array}{l}\text { Total direct } \\
\text { costs€million }\end{array}$ \\
\hline Burglaries & 497.9 & 11.7 & 4,770 & 2,004 & 9.6 \\
\hline Robberies & 37.79 & 0.3 & 102 & 22,529 & 2.3 \\
\hline $\begin{array}{l}\text { Aggravated } \\
\text { assaults }\end{array}$ & 172.8 & 5.4 & 2,206 & 20,058 & 44.3 \\
\hline Rape & 15.5 & 0.4 & 171 & 27,990 & 4.8 \\
\hline Murder & 1.33 & 0.1 & 29 & 30,645 & 0.9 \\
\hline
\end{tabular}

a: calculated using data from the National Observatory of the delinquency, 2009[44] b: (Nevin, 2006) by using French rate crime[36] c: calculated data from (Arlaud, 2006)[46] d: calculated data from the US Bureau of Justice Statistics inflated to 2008[47].

Table 3 shows the effect of developmental lead exposure on crime in France and the associated annual costs. We first informed on the number of the selected crimes per 100,000 French residents committed in 2008: 497.9 burglaries, 37.79 robberies, 172.8 aggravated assaults, 15.5 rapes and 1.33 murders. US Lead linked crimes (with US crime rate $(5.6$ per 100,000)), estimated by Nevin, were adapted to the French crime rate $(1.7$ per 100,000$):$ we obtained $11.7($ e.g. $=(38.7 / 5.6) * 1.7)$ burglaries, 0.3 robberies, 5.4 aggravated assaults, 0.4 rape and 0.1 murder for lead linked crimes per 100,000 French residents. We calculated the total lead linked crimes for the French population aged 13-60 years. We then used French and US available data for the direct costs per crime and multiply these latter with total lead linked crimes to obtain the total direct costs per year ( $€ 61.8$ million in 2008). 
Table 4 Total Benefits and total cumulated benefits per year (in $\epsilon_{2008}$ Billion)

\begin{tabular}{lccccc}
\hline Blood-lead concentrations range $(\boldsymbol{\mu} \mathbf{g} / \mathbf{L})$ & Bmed & Bsocietal & Total benefits & Hypothetical threshold values $(\boldsymbol{\mu} \mathbf{g} / \mathbf{L})$ & Total cumulated benefits \\
\hline $15 \leq \mathrm{B}-\mathrm{Pb}<24$ & 0.198 & 11.8 & $11.99(1)$ & $\mathrm{B}-\mathrm{Pb} \geq 15$ & $22.72(1+2+3)$ \\
\hline $24 \leq \mathrm{B}-\mathrm{Pb}<100$ & 0.083 & 10.2 & $10.28(2)$ & $\mathrm{B}-\mathrm{Pb} \geq 24$ & $10.72(2+3)$ \\
\hline $\mathrm{B}-\mathrm{Pb} \geq 100$ & 0.016 & 0.44 & $0.44(3)$ & $\mathrm{B}-\mathrm{Pb} \geq 100$ & 0.44
\end{tabular}

Table 4 shows the estimated total benefits ranged from blood-lead concentrations and total cumulated benefits based on three hypothetical values per year. We first differenced the estimated medical benefits (Bmed) and the societal benefits (Bsocietal) ranged from blood-lead concentrations:

The $15-24 \mu \mathrm{g} / \mathrm{L}$ Bmed, the $24-100 \mu \mathrm{g} / \mathrm{L}$ Bmed and the $\geq 100 \mu \mathrm{g} / \mathrm{L}$ Bmed are the $B_{\text {screening15-24 }}\left(€ 0.198\right.$ Billion), the $B_{\text {screening24-100 }}\left(€ 0.083\right.$ billion) and the $B_{\text {treatment } \geq}$ 100 (€0.016 billion), respectively.

The $15-24 \mu \mathrm{g} / \mathrm{L}$ Bsocietal, the $24-100 \mu \mathrm{g} / \mathrm{L}$ Bsocietal and the $\geq 100 \mu \mathrm{g} / \mathrm{L}$ Bsocietal are the $B_{\text {earn } 15-24}$ discounted ( $€ 11.8$ billions), The $B_{\text {earn24-100 }}$ discounted ( $€ 10.2$ billions) and the $B_{\text {earn } \geq 100}$ discounted added to the $B_{\text {spec.ed } \geq 100}$, the $B_{\text {crime } \geq 100}$ and the $B_{\text {other }} \geq 100$ ( $€ 0.44$ billion), respectively. The $B_{\text {spec.ed } \geq 100}$ equal to $€ 0.01453$ billion [(10\% of the French population of children $3-6$ years) $((79.8 \% * 38,958)+(20.1 \% * 48,255))]$, the $B_{\text {crime } \geq 100}$ equal to $€ 0.0618$ billion and the $B_{\text {other }} \geq 100$ equal to $€ 0.0427$ billion, which are the intangible avoided costs. We estimated the total benefits (Bmed +Bsocietal) ranged from blood-lead concentrations: $€ 11.99$ billions (1), €10,28 billions (2) and $€ 0.44$ billion (3).

We secondly estimated total cumulated benefits per year based on the three hypothetical threshold values, above 15,24 and $100 \mu \mathrm{g} / \mathrm{L}$. We obtained $€ 22.72$ billions $(1+2+3)$, $€ 10.72$ billions $(2+3)$ and $€ 0.44$ billion (3), respectively.

According to the hypothetical threshold values, they ranged from $€ 3.78$ billion, $€ 1.88$ billion and $€ 0.25$ billion respectively for children aged 1-6 years in the 2008 cohort, as shown in Table 6.

Reported per child, and given the number of children across hypothetical threshold values (i.e number of children from $\geq 15 \mu \mathrm{g} / \mathrm{L}$, from $\geq 24 \mu \mathrm{g} / \mathrm{L}$ and from $\geq 100$ $\mu \mathrm{g} / \mathrm{L}$, respectively), the yearly estimate of net benefit per child (2008) ranged from $€ 1,610, € 2,710$ and $€ 46,878$, respectively.

\section{Discussion}

The aim of this paper was to provide an economic evaluation of the health impacts of children with lead exposure in France. Based on the assumption of the EFSA report [1], that there is no threshold of lead exposure, our study provides a range of annual benefits and partial costs estimated in order to highlight the economic impact for society of lead exposure reduction policies below the conventional $\mathrm{B}-\mathrm{Pb}$ screening value of $100 \mu \mathrm{g} /$
L. Several hypothetical threshold values for intoxication $(15,24,100 \mu \mathrm{g} / \mathrm{L}$, respectively) were chosen following a "what if" approach. We have no strong data to choose levels lower than $15 \mu \mathrm{g} / \mathrm{L}$ but also do not assume it to be a safe exposure level. The partial cost benefit analysis documents a clear cost effectiveness of lead hazard control, which should result in benefits greatly superior to the costs, as suggested by the comparison of the sum of benefits to that of congruent costs for one year. This study showed that by reducing childhood lead exposure, large social benefits might be produced for the birth cohort of 2008 (and subsequent years): $€ 22.72$ billion, $€$ 10.72 billion and $€ 0.44$ billion, respectively. The benefits were mainly due to the social avoided costs, specifically the lost life time earnings, at exposures corresponding to $\mathrm{B}-\mathrm{Pb}<100 \mu \mathrm{g} / \mathrm{L}$. There are some limitations to our analysis, due in particular to access to figures related to avoided costs and to costs of exposure reduction as we will see below. This is the reason why we could not perform a complete CBA. Direct health costs were also

Table 5 Costs to decontaminate French houses with lead-based paint $\left(\epsilon_{\mathbf{2 0 0 8}}\right)$

\begin{tabular}{lccr}
\hline Type of costs & Cost1 per home & Cost2 per home & Cost3 per home \\
\hline Global environmental survey & $381^{\mathrm{a}}$ & $381^{\mathrm{a}}$ & $381^{\mathrm{a}}$ \\
\hline Home dust analysis & $30^{\mathrm{b}}$ & $30^{\mathrm{b}}$ & $30^{\mathrm{b}}$ \\
\hline Home paint analysis & $30^{\mathrm{b}}$ & $30^{\mathrm{b}}$ & $30^{\mathrm{b}}$ \\
\hline ANAH's assumptions & $2,600^{\mathrm{c} 1}$ & $5,600^{\mathrm{c}}$ & $8,200^{\mathrm{c3}}$ \\
\hline Housing substitutes & $521^{\mathrm{d}}$ & $521^{\mathrm{d}}$ & $521^{\mathrm{d}}$ \\
\hline Overall interventions & 3,562 & 6,562 & 9,162 \\
\hline Total costs (Emillion) & 133.1 & 245.3 & 342.5 \\
\hline
\end{tabular}

$\mathrm{a}=$ Argeron, 1995, actualized in 2008 by INVS [3]. $\mathrm{b}=$ LERES, 2009[54]. $\mathrm{c}=$ The National Agency of the housing environment (ANAH)[53], 2010., $\mathrm{d}=$ Mc Laine and colleagues.,2006, €2008[55].

Table 5 presents lead-based paint decontamination costs per home. We used French data for global environmental survey (€381) and for home dust and home paint analysis (€30, each one). We used also the assumptions of ANAH works for estimating the removal of lead-based paint cost per home eliminating lead. These assumptions were the following ones: Assumption 1: a $20 \%$ max rate was applied to $€ 13,000$ standard works for rehabilitating old houses <1949, irrespective any lead-based paint intervention. Assumption 2: a $70 \%$ max rate was applied to $€ 8,000$ works of specific lead decontamination Assumption 3 : Assumptions 1 \& 2 combined, i.e. the max mix of two works.

The housing substitutes, $€ 521$, were US data based on Mc Laine analysis. Based on these data and assumptions, we calculated three overall interventions ranged from $€ 3,562$ to $€ 9,162$ and three total lead-based paint decontamination costs ranged from $€ 133.1$ to $€ 342$ million, which were performed on the 37,382 houses concerned, in one shot for one year. 
Table 6 Net benefits of the removal of lead-based paint in French houses (in $\epsilon_{2008}$ Billion)

\begin{tabular}{lccccc}
\hline $\begin{array}{l}\text { Blood-lead concentrations range } \\
(\mu \mathrm{g} / \mathrm{L})\end{array}$ & Benefits & $\begin{array}{c}\text { Abatement } \\
\text { costs }\end{array}$ & $\begin{array}{c}\text { Net } \\
\text { benefits }\end{array}$ & $\begin{array}{c}\text { Hypothetical threshold values } \\
(\boldsymbol{\mu g} / \mathrm{L})\end{array}$ & $\begin{array}{c}\text { Net cumulated } \\
\text { benefits }\end{array}$ \\
\hline $\mathbf{1 5} \leq \mathrm{B}-\mathrm{Pb}<\mathbf{2 4}$ & 1.92 & $0.016(0.008-0.02)$ & $\mathbf{1 . 9 0}(\mathbf{1})$ & $\mathrm{B}-\mathrm{Pb} \geq \mathbf{1 5}$ & $\mathbf{3 . 7 8}(\mathbf{1 + 2 + 3})$ \\
\hline $\mathbf{2 4} \leq \mathrm{B}-\mathrm{Pb}<\mathbf{1 0 0}$ & 1.64 & $0.016(0.008-0.02)$ & $\mathbf{1 . 6 3 ( 2 )}$ & $\mathrm{B}-\mathrm{Pb} \geq \mathbf{2 4}$ & $\mathbf{1 . 8 8}(\mathbf{2 + 3})$ \\
\hline $\mathrm{B}-\mathrm{Pb} \geq \mathbf{1 0 0}$ & 0.33 & $\begin{array}{c}0.074(0.037- \\
0.104)\end{array}$ & $\mathbf{0 . 2 5}(\mathbf{3})$ & $\mathrm{B}-\mathrm{Pb} \geq 100$ & $\mathbf{0 . 2 5}$ \\
& & & & \\
\hline
\end{tabular}

Table 6 presents the net benefits of the removal of lead-based paint in French houses. Lead in soils and dust from the lead-based paint in homes built before 1949 represented $16 \%$ and $74 \%$ of cases of childhood lead intoxication for B-Pb concentration $15-100 \mu \mathrm{g} / \mathrm{L}$ and for B-Pb concentration $\geq 100 \mu \mathrm{g} / \mathrm{L}$, respectively. We applied these percentages to calculate the total benefits and the total costs C*paint (with central estimates selected) of the removal of lead-based paint ranged from blood-lead concentrations. We obtained $€ 1.92$ billion(=€11.99billion* $16 \%)$ and $€ 0.016$ billion $\left.\left(=\left(€ 0.2453 / W_{30}\right)^{*} 16 \%\right)\right)$ for the $15-24 \mu \mathrm{g} / \mathrm{L}$ range, $€ 1.64$ billion $\left(=€ 10.28^{*} 16 \%\right)$ and $€ 0.016$ billion $\left(=\left(€ 0.2453 / \mathrm{w}_{30}\right)^{*} 16 \%\right)$ ) for the $24-100 \mu \mathrm{g} / \mathrm{L}$ range, and $€ 0.33$ billion $\left(=€ 0.44\right.$ billion*74\%) and $\left(=\left(€ 0.2453 / \mathrm{W}_{30}\right)^{*} 74 \%\right)$ ) for the $\geq 100 \mu \mathrm{g} / \mathrm{L}$ range, respectively. We thus calculated the net benefits of the removal of lead-based paint ranged from blood-lead concentrations: $€ 1.90$ billion (1), $€ 1.63$ billion ( 2 ) and $€ 0.25$ billion (3) for B-Pb concentration $15-24,24-100 \mu \mathrm{g} / \mathrm{L}$ and B-Pb concentration $\geq 100 \mu \mathrm{g} / \mathrm{L}$, respectively. Based on the three hypothetical threshold values, above 15,24 and $100 \mu \mathrm{g} / \mathrm{L}$, we estimated also the total net benefit cumulated: $€ 3.78$ billions $(1+2+3)$, $€ 1.88$ billion $(2+3)$ and $€ 0.25$ billion (3), respectively.

estimated but they were probably underestimated. Lead exposure provokes other health impacts besides cognitive disorders which were not assessed in this paper, such as cardiovascular diseases and cancer that lead to premature mortality. This would yield higher social costs than IQ decrement alone [56]. We disregarded for instance, drug costs and medical intervention costs such as intravenous chelation. Among other costs, the pretium doloris calculated on the basis of $€ 8,000$ per child in the Metal Blanc judgment was certainly underestimated, because only a small part of the children have been compensated, while also neglecting the psychological and economic suffering of the family or household of the children affected. We also estimated the need for special education to be $10 \%$ for children with $\mathrm{B}-\mathrm{Pb} \geq 100 \mu \mathrm{g} / \mathrm{L}$. The somewhat uncertain data on crime costs suggest that the economic impact is comparatively low, but the costs of crime and rape were probably underestimated, because they did not include the value of statistical life, which may be greater than that of accidents (between $€_{1999} 0.5$ to 1.5 million in Europe and French estimations were the lowest bracket estimate) $[57,58]$.

They highlight the additional social consequences of lead pollution. In regard to annual costs to invest in pollution abatement, our preliminary estimates are affected by the paucity of available data. We could not make a complete CBA because of lack of available data on the abatement costs, we had a very small part of the industrial costs. Official data from the ministry of Environment show that the major industrial sources of lead in France are the metals and non metallic minerals sectors [59]. Three quarters of the 2007 emissions took place through water, and two waste treatment facilities alone amounted to $60 \%$ of total emissions of the ten most emitting facilities [60]. We had also quite imprecise cost estimates for substitution of lead pipes, whose yearly estimates are certainly exaggerated. So far, clean-up costs of industrial lead-contaminated sites cannot be evaluated in France. Partial data stem from the experience of the highly polluted MetalEurop site remediated by SITA-Suez Environment, which amounted to $€ 28$ million [61]. Unfortunately, these findings cannot be extrapolated to the national situation. As to contaminated sites, we point out the need for a specific evaluation. However, costs to decontaminate French houses with lead-based paint were available. And we calculated these costs once-for-all in one year, even if we overestimated the annual expenses, they appeared to be the most important efforts to be made in order to control the hazard. We could express an equivalent annual cost by using the capital recovery factor of standard interest calculations for loans which is the appropriate conversion factor. However, uncertainties remain regarding the time horizon and the social discount rate to use. A 0.05 conversion factor between one-time cost and annual cost is a compromise.

Some of the costs were paid within one year or paid over no more than five years, costs would be substantially less subsequent to that, while benefits would continue to accrue for each new birth cohort being born during the following years.

Our first estimates of total net benefit induced by reducing exposure to soils and dust in respect of the costs incurred by the decontamination of French houses with lead-based paint highlight that policies aimed at reducing lead exposures had an overall positive societal and economic impact. Additional estimates of total net benefit were performed, that considered the costs associated with dust and soils and drinking water lead pipes substitution. The expected health gains, according to the different $\mathrm{B}-\mathrm{Pb}$ hypothetical threshold values, were calculated to be $€ 3.9$ to 4 billion, $€ 1.86-2$ billion and $€ 0.12$ 0.25 billion respectively. The corresponding figures per child range from $€ 1,661$ to $€ 1,721, € 2,666$ to $€ 2,861$, and $€ 21,939$ to $€ 47,815$, respectively. These estimates should be considered with caution, because of the uncertainty in the quality of data on costs of lead water pipes removal; a specific evaluation is also needed here. 
Various uncertainties exist in our calculations: benefits linked to the dose-response function, and monetary valuation of the abatement costs linked to houses remediation, which yield uncertainties in the partial cost benefit estimates. According to Rabl and colleagues, there is a factor two uncertainty, both in the dose-response function and in the monetary valuation $[62,63]$. Should the scientific literature show some day evidence of lower toxicity level values than the one we used in this sensitivity analysis, the health cost figures would be substantially increased.

The overall return of investments is important and must be taken into account by the policy makers. They are in line with several US findings that illustrate how reduction of childhood lead exposure has a high social benefit, in particular the studies from Schwartz [16], Salkever [17] and Grosse and colleagues [64]. Between 1976 and 1999, Grosse et al. [64] estimated the economic impact of the trend of reduced lead exposure over 25 years in a cohort of children starting at 2 years of age in 2000. The estimate cost was valued from $\$ 110$ to $\$ 319$ billion (US) for the cohort each year, comparing it as if the blood lead concentration were that same as in 1975. Landrigan et al. [34] estimated the total annual costs of childhood lead poisoning to be $\$_{1997} 43$ billion in each birth cohort exposed to lead in the US. Their methodological approach was based on the contribution of environmental pollutants by using an Environmentally Attributable Fraction (EAF) model, which was estimated at $100 \%$ for lead poisoning. Recent studies calculated the economic impact of childhood poisoning below $100 \mu \mathrm{g} / \mathrm{L}$. The most recent major U.S. study was that of Gould [8]. It was more comprehensive than those previously published, and produced a CBA by comparing the estimated costs in 1996 related to cleanup of lead-containing paint in the U.S. (\$ 1 - \$11 billion (US)) and secondly, by calculating the monetary benefits and social benefits by reducing lead exposure for a cohort of children $<6$ years (\$192 - \$270 billion) with earning losses amounted to $87 \%$ of total avoided costs. Total net benefits amounted to $\$ 181$ - \$ 269 billion. Therefore, a specific calculation induced by lead-based paint was not performed in this study. Muennig et al. [65], whereas, provided information on the benefits that might be realized if all children in the United States had a blood lead level of less than $10 \mu \mathrm{g} / \mathrm{L}$. The net societal benefits showed improvements in high school graduation rates and reductions in crime would amount to $\$ 50,000$ (SD, $\$ 14,000)$ per child annually at a discount rate of $3 \%$. This would result in overall savings of approximately $\$ 1.2$ trillion (SD, $\$ 341$ billion) and produce an additional 4.8 million QALYs (SD, 2 million QALYs) for the US society as a whole.
Researchers in other European countries with prevalence of lead exposures similar to French figures may use this as a guide as to undertake similar economic assessments. Additionally, these data may motivate the revision of the current French policies as to whether or not to intervene in regard to lead pollution, and, in a more general sense, revamping France's overall policy on reducing pollution that may be affecting children's development. The introduction of unleaded petrol has greatly decreased emissions of lead in the atmosphere in France and globally. (Paris ambient air concentrations decreased by 97\% between 1991 and 2005)[66]. The relative benefits of this action were substantial [3] and likely much greater than the benefits from further reduction of $\mathrm{B}-\mathrm{Pb}$ levels today. Nonetheless, much abatement remains to be done, as other sources are only slowly being removed, if at all. The screening of houses for sale or rent with lead-based paint was implemented through the 2004 Public Health Act and its stringent policies on industrial emissions were triggered by EU regulations. The French 2004 national environmental health action plan has also contributed to the steady decrease in exposure of the general population and of its most vulnerable young segment over the last years in France.

EFSA recommends that "work should continue to reduce exposure to lead, from both dietary and nondietary sources" [1]. The major prevention campaigns aim to reduce lead exposure to the lowest possible level in order to protect children and childbearing age women. The obtained benefits for exposure levels $<100$ $\mu \mathrm{g} / \mathrm{L}$ in this study are in line with the EFSA recommendations. They are a first step evaluation which should be expanded and refined. Our results emphasize the substantial monetary advantages obtained from preventing losses of a few IQ points because of lead exposures among children. While 1-point change in Full Scale IQ score is within the standard error of an individual's single measurement, it may be highly significant on a population basis [25].

\section{Conclusions}

The primary economic benefits of policies focused on lead exposure abatement are the further reduction of low blood lead levels. In contrast, prevention of cases with $\mathrm{B}-\mathrm{Pb}>100 \mu \mathrm{g} / \mathrm{L}$ accounts for much lower benefits. This is because children with milder exposures are much more common and they still benefit from decreased exposure, as there is no known safe level of lead exposure. Lead toxicity is still a serious public health issue, despite the present low prevalence of unacceptably high $\mathrm{B}-\mathrm{Pb}$ concentrations. Public policies to prevent lead exposure will reduce future medical expenses and the reduce the burden on special 
education classes. More importantly, they will also increase the productivity of children during their adult lives. Our CBA results suggest that overall reduction of costs due to toxicity can be achieved by further control of major contact media, including food, through diffusion of lead in the environment from industrial releases and also by further control of residential sources (leaded paint, deteriorated housing, old water pipes). In addition to abating the burden of developmental impairment in general, these policies will also help to reduce health disparities. This objective calls for prioritized policies focused on the most highly exposed communities and individuals. This combined strategy is a policy issue that our data aim to inspire. Yet, additional documentation of the $\mathrm{B}-\mathrm{Pb}$ values for further evaluation is needed. A more thorough evaluation of the marginal costs of the measures to be taken is also needed in order to balance lead exposure abatement options.

\section{List of Abbreviations}

AFSSA: French Food Safety Agency; ANAH: National Agency of the Housing Environment; B-Pb: blood-lead; CBA: cost benefit analysis; CEPA: California Environmental Protection Agency; COI: Cost of illness; CSHPF: High Council of Hygiene; EAF: Environmentally Attributable Fraction; EFSA: European Food Authority Safety; GDP: Gross Domestic Product; IEGRE: European Institute Reasoned Management for the Environment; IME: Medical Educational Institutes; INERIS: National Institute for Industrial Environment and Risks; INSERM: National Institute of Health and Medical Research; INSEE: National Institute for Statistics and Studies; InVS: French Institute for Public Health Surveillance; IQ: Intellectual Quotient; ITEP: Educational and Therapeutic Institutes; LERES: Laboratory study and research in environment and health; PPP: Purchasing Power Parity; QALY: Quality-Adjusted Life Year; SNSPE: French National system of surveillance of children's B-Pb concentrations.

\section{Acknowledgements}

We would like to thank Olivier Chanel of GREQAM-IDEP, Philippe Bretin of InVS, Laurent Girometti of ANAH, Barbara Le Bot and Bernard Lucas of EHESP for their technical support.

\section{Author details}

'EHESP School of Public Health, CS 74312 - 35043 Rennes Cedex, France. 2INSERM U 954 "Nutrition, genetics and environmental risks", Medical School, 9 av de la Forêt de Haye - BP 1854505 Vandoeuvre-les-Nancy Cedex, France. ${ }^{3}$ Nancy University Medical School, Public Health department, Vandoeuvre-les-Nancy Cedex, France. ${ }^{4}$ Institute of Public Health University of Southern Denmark, J. B Winsloewsvej 17, DK-5000 Odense, Denmark. ${ }^{5}$ Department of Environmental Health, Harvard School of Public Health, Boston MA 02215, USA. ${ }^{6}$ IRSET-Research Institute for Environmental and Occupational Health-INSERM U625, Rennes, France.

\section{Authors' contributions}

CP performed the literature review, drafted the manuscript and carried out the analysis. MB, DZN, PGr, PGI and PH contributed substantially to defining the methods of the analysis, interpreting the results of the study and editing the manuscript. All authors read and approved the final version.

\section{Competing interests}

The authors declare that they have no competing interests. PGr is an editorin-chief of Environmental Health, but was not involved in the editorial handling of this manuscript.

Received: 31 January 2011 Accepted: 20 May 2011 Published: 20 May 2011

\section{References}

1. European Food Authority Safety (EFSA): Panel on Contaminants in the Food Chain (CONTAM); Scientific Opinion on Lead in Food. Journal 2010, 8:1570[http://www.efsa.europa.eu], [147 pp.]..

2. INSERM (INSTITUT NATIONAL DE LA SANTE ET LA RECHERCHE MEDICALE): Plomb dans l'environnement: Quels risques pour la santé ? In Expertise collective Edited by: Inserm Paris 1999.

3. INVS (Institut National de Veille Sanitaire): Saturnisme, Quelles stratégies de dépistage chez l'enfant ? Expertise opérationnelle.Edited by: Inserm Paris 2008.

4. Glorennec P, Bemrah N, Tard A, Robin A, le Bot B, Bard D: Probabilistic modelling of young children's overall lead exposure in France: integrated approach for various exposure media. Environ Int 2007 33:937-945.

5. CITEPA. Centre Inter-professionnel d'Etude de la Pollution Atmosphérique: Emissions dans l'air en France. Citepa 2004, 28-34.

6. Glorennec P, Ledrans M, Fabres B: Decision tools for selecting industrial sites where a systematic blood lead screening should be implemented Masson, Paris, 2006. Rev Epidemiol Sante Publique 2006, 54:117-125.

7. Hivert G, Coquet S, Glorennec P, Bard D: Is compliance to current regulation safe enough for infants and toddlers? Rev Epidemiol Sante Publique 2002.

8. Gould E: Childhood Lead Poisoning: Conservative Estimates of the Social and Economic Benefits of Lead Hazard Control. Environmental Health Perspectives 2009, 117:1162-1167.

9. Grandjean P: Colloque Environnement chimique, reproduction et développement de l'enfant: 25 November 2008 Paris. MEEDAT; 2008.

10. Grandjean P, Weihe P, White RF, Debes F, Araki S, Yokoyama K, Murata K, Sorensen N, Dahl R, Jorgensen PJ: Cognitive deficit in 7-year-old children with prenatal exposure to methylmercury. Neurotoxicol Teratol 1997, 19:417-428.

11. Rudnai P: Blood lead levels in children. WHO-ENHIS (World Health Organization-European ENvironment and Health Information System): May 2007, Fact sheet $N^{\circ} 4.5$

12. Etchevers $A$, Lecoffre $C$, Le Tertre $A$, Le Strat $Y$, Groupe Investigateurs Saturn-Inf, de Launay C, Bérat B, Bidondo ML, Pascal M, Fréry N, de CrouyChanel P, Stempfelet M, Salomez JL, Bretin P: Imprégnation des enfants par le plomb en France en 2008-2009. Blood lead level in children in France, 2008-2009.[http://www.invs.sante.fr/behweb/2010/02/index.htm], BEHWeb 2010 (2)..

13. Bellinger DC: Very low lead exposures and children's neurodevelopment. Curr Opin Pediatr 2008, 20:172-177.

14. Lanphear BP, Hornung R, Khoury J, Yolton K, Baghurst P, Bellinger DC, Canfield RL, Dietrich KN, Bornschein R, Greene T, Rothenberg SJ, Needleman HL, Schnaas L, Wasserman G, Graziano J, Roberts R: Low-level environmental lead exposure and children's intellectual function: an international pooled analysis. Environ Health Perspectives 2005, 113:894-899.

15. Needlemann HL: Lead poisoning. Annu Rev Med 2004, 55:209-222.

16. Schwartz J: Societal benefits of reducing lead exposure. Environ Res 1994, 66:105-124.

17. Salkever DS: Updated estimates of earnings benefits from reduced exposure of children to environmental lead. Environ Res 1995, 70:1-6.

18. Chanel O: Approches économiques et socio-économiques, in Plomb dans I'Environnement: Quels risques pour la santé.Edited by: INSERM 1999.

19. Chanel O: Apports de l'analyse économique, In Saturnisme Quelles stratégies de dépistage chez l'enfant ?Edited by: INSERM, Paris 2008, 215-229.

20. Chanel O: L'analyse coût-bénéfice en santé environnementale, in Science et décision en santé environnementale. Collection Santé et Société $n^{\circ} 6$ 1997, 52-63.

21. Fassin D, Naudé A-J: Plumbism reinvented.Childhood lead poisoning in France, 1985-1990. Public Health then and now. American journal of Public Health; 2004:94(11):1854-1863.

22. Lecoffre $C$, Provini $C$, Bretin P: Dépistage du saturnisme chez l'enfant en France de 2005 à 2007. Saint-Maurice (Fra): Institut de veille sanitaire; 2010, 109[http://www.invs.sante.fr].

23. Levin R, Brown MJ, Kashtock ME, Jacobs DE, Whelan EA, Rodman J, Schock MR, Padilla A, Sinks T: Lead exposure in U.S. children, 2008: implications for prevention. Environ Health Perspect 2008, 116:1285-1293. 
24. California Environmental Protection Agency: Development of Health Criteria for School Site Risk Assessment Pursuant to Health and Safety Code Section 901(g): Child-Specific Benchmark Change in Blood Lead Concentration for School Site Risk Assessment. Final report. Sacramento, CA:California Environmental Protection Agency, Office of Environmental Health Hazard Assessment; 2007 [http://www.oehha.ca.gov/public_info/ public/kids/pdf/PbHGV041307.pdf], [accessed 2 March 2009].

25. Miodovnik A, Landrigan PJ: The U.S. Food and Drug Administration Risk Assessment on Lead in Women's and Children's Vitamins Is Based on Outdated Assumptions. Environmental Health Perspectives 2009, 117:1021-1022.

26. Pearce D, Atkinson G, Mourato S: Cost Benefit Analysis and the Environment, Recent developments. OECD (ORGANISATION FOR ECONOMIC CO-OPERATION AND DEVELOPMENT) publishing; 2006.

27. Drummond MF, Stoddart GL: Economic evaluation of health-producing technologies across different sectors: can valid methods be developed? Health Policy 1995, 33:219-231.

28. Drummond MF, Sculpher Mark J, Torrance George W, O'Brien Bernie J, Stoddart Greg L: Methods for the Economic Evaluation of Health Care Programmes. Oxford University press; 2005.

29. Base CODECS: Guide référentiel destine à l'élaboration d'une fiche analytique. Collège des Economistes de la Santé V7 2004.

30. Treich N: Analyse Coût bénéfice et risque. enjeux et pratiques., Journée ICSI-LERNA (04/04/2006). LERNA-INRA.

31. French Ministry of Health direction générale de la santé: L'intoxication par le plomb de l'enfant et de la femme enceinte: Dépistage. Prise en charge. 2006, 2.

32. Brown MJ: Costs and benefits of enforcing policies to prevent childhood poisoning. Medical Decision Making 2002, 22:482-492.

33. IGAS (INSPECTION GENERALE DES AFFAIRES SOCIALES): Lutte contre le saturnisme infantile lie à l'habitat indigne. Analyse du dispositif dans trois departements d'lle de France. Rapport n²004-034, mars 2004, 160.

34. Landrigan PJ, Schechter CB, Lipton JM, Fahs MC, Schwartz J: Environmental pollutants and disease in American children: Estimates of morbidity, mortality, and costs for lead poisoning, asthma, cancer, and developmental disabilities. Environ Health Perspect 2002, 110:721-708.

35. Nevin R, Jacobs DE, Berg M, Cohen J: Monetary benefits of preventing childhood lead poisoning with lead-safe window replacement. Environ Res 2008, 106:410-419.

36. Nevin R: Understanding international crime trends: the legacy of preschool lead exposure. Environ Res 2006, 104:315-336.

37. Lyngbye T, Hansen ON, Trillingsgaard A, Beese I, Grandjean P: Learning disabilities in children: significance of low-level lead-exposure and confounding factors. Acta Paed Scand 1990, 79:352-60.

38. Espagnol P, Prochandy P, Raynaud P, Tremoureux C: La scolarisation des enfants et adolescents handicapés. Etude et résultats, DREES, №264. 2007.

39. Wang Q, Zhao Hh, Chen Jw: Study on health effect of environmental lead exposure in children. Chinese Journal of Public Health 2009, R179.

40. CRAM de Bretagne: Production d'Informations Synthétisées MédicoSociales-ratios nationaux. Structures pour enfants et adultes handicapés. Analyse régionale secteur médico-social en 2008. 2010.

41. Wright JP, Dietrich KN, Ris MD, Hornung RW, Wessel SD, Lanphear BP, Ho M, Rae MN: Association of prenatal and childhood blood lead concentrations with criminal arrests in early adulthood. PLoS Med 2008, 5:e101.

42. Needleman H, McFarland C, Ness R, Fienberg S, Tobin M: Bone lead levels in adjudicated delinquents. A case control study. Neurotoxicol Teratol 2003, 24:711-717.

43. Dietrich K, Ris M, Succop P, Berger O, Bornschein R: Early exposure to lead and juvenile delinquency. Neurotoxicol Teratol 2001, 23:511-518.

44. Bauer A: Criminalité et délinquance. Bulletin mensuel de l'observatoire national de la délinquance; 2009.

45. INSEE (National Institute of Statistics and Economic Studies): La situation démographique en 2006., INSEE résultats..

46. Arlaud JP: Delinquance et insécurité. Combien ça vous coûte ? Publibook. 2007

47. U.S. Bureau of Justice Statistics, Department of Justice: "Cost of Crime". Washington, DC:U.S. Department of Justice; 2004.

48. Department of Justice - Federal Bureau of Investigation (USA): "Crime in the United States by Volume and Rate per 100,000 Inhabitants, 19892008"]. Crime in the United States 2008 2009-09.
49. Tavares C, Thomas G: Crime and criminal justice. Statistics in focus. 2007 [http://epp.eurostat.ec.europa.eu/cache/ITY_OFFPUB/KS-SF-07-015/EN/KS-SF07-015-EN.PDF], Population and social conditions. Eurostat..

50. Association protection défense de l'environnement de Bourg Fidèle:[http:// www.bourgfidele.lautre.net/].

51. Brignon JM, Soleille S: Données technico-économiques sur les substances chimiques en France. INERIS (French National Institut for Industrial Environment and RISks) DRC-Meco 1; 2005.

52. Garrigues D: La tragi-comédie du plomb dans l'eau du robinet. IEGRE (European Institute Reasoned Management of the Environment); 2009.

53. ANAH. [http://www.anah.fr/]

54. LERES. [http://leres.ehesp.fr/]

55. MCLaine P, Shields W, Farfel M, Chilsom JRJJ, Dixon SA: Coordinated relocation strategy for enhancing case management of lead poisoned children: Outcomes and costs. Journal of Urban Health: Bulletin of the New York Academy of Medicine 2006, 83:111-128.

56. Menke A, Muntner P, Batuman V, Silbergeld EK, Guallar E: Blood lead below $0.48 \mathrm{mmol} / \mathrm{L}(10 \mathrm{mg} / \mathrm{dL})$ and mortality among US adults. Circulation 2006, 114:1388-1394, 2006.

57. Commissariat General du Plan, Boiteux M, Baumstark L: Transports: choix des investissements et coût des nuisances. La documentation française; 2001, 325[http://lesrapports.ladocumentationfrancaise.fr/BRP/014000434/ 0000.pdf].

58. Desaigues B, Rabl A: Reference Values for Human Life. Kluwer Academic Publishers; 1995

59. Indicateurs de suivi des engagements européens:[http://www.stats. environnement.developpementdurable.gouv.fr/indicateurs/indicateurs-desuivi-des-engagements-europeens/indicateurs-de-suivi-des-engagementseuropeens/emissions-nationales-de-metaux-lourds-dans-l-air-cadmiummercure-plomb.html].

60. irep. [http://www.irep.ecologie.gouv.fr/REP/index.php].

61. Charles Gauthier: Metaleurop, cinq ans après. Le Figaro magazine.

62. Spadaro JV, Rabl A: Estimating the Uncertainty of Damage Costs of Pollution: a Simple Transparent Method and Typical Results. Environmental Impact Assessment Review 2008, 28:166-183.

63. Spadaro JV, Rabl A: Pathway Analysis for Population-Total Health Impacts of Toxic Metal Emissions. Risk Analysis 2004, 24(5):1121-1141.

64. Grosse SD, Matte TD, Schwartz J, Jackson RJ: Economic gains resulting from the reduction in children's exposure to lead in the United States. Environ Health Perspect 2002, 110:563-569.

65. Muennig P: The social costs of childhood lead exposure in the post-lead regulation era. Arch Pediatr Adolesc Med 2009, 163(9):844-849.

66. airparif. [http://www.airparif.asso.fr/page.php?rubrique=polluants].

\section{doi:10.1186/1476-069X-10-44}

Cite this article as: Pichery et al.: Childhood lead exposure in France: benefit estimation and partial cost-benefit analysis of lead hazard control. Environmental Health 2011 10:44.

\section{Submit your next manuscript to BioMed Central and take full advantage of:}

- Convenient online submission

- Thorough peer review

- No space constraints or color figure charges

- Immediate publication on acceptance

- Inclusion in PubMed, CAS, Scopus and Google Scholar

- Research which is freely available for redistribution

Submit your manuscript at www.biomedcentral.com/submit
C Biomed Central 